\title{
Security Problems within Post-Soviet Space
}

\section{Nika Chitadze*}

The problems of security within the territory of the former Soviet Union are numerous. The security architecture in the CIS is still in the process of formation, which complicates the situation. The situation in the CIS represents a combination of many factors, such as:

- The disintegration of a huge, multiethnic, totalitarian empire;

- The security asymmetry between powerful ex-hegemony and weak neighbors;

- The weakness of state institutions in all members of the CIS;

- The dominance of ethnic nationalism;

- The simultaneous processes of reintegration and disintegration;

- The absence of democratic traditions in local political and economic culture and weakness of civil society;

- The continuing presence of the Soviet mentality and Soviet management culture among the representatives of the state authorities;

- The deep social and economic crisis in all states of the CIS, which is caused by the transition from a planned to market economy.

As a rule, the tactics and priorities of national security determine the overall security concept of sovereign states. The CIS states have not yet managed to clearly work out their own security concepts. Even Russia, in spite of its long experience of sovereign statehood and its central role in the former USSR, has been unable to definitively articulate its own security interests. As for other states within the CIS, the problems of national security have turned out to be a real test for the new political elites, who lack necessary experience, a foundation in strategic culture, and ability in foreign-policy planning. The definition of security interests represents a very difficult task for all states of the CIS. The reasons for this are the unsettled political and economic status of the region, unpredictable dynamics of the internal development process of the CIS, and security codes and relations among the CIS states, as well as between the CIS and the rest of the world. Newly independent states have found themselves in an international system where sovereign states act according to their national interests. Now the CIS states must try to determine their role and function in both the regional and global contexts, and identify their top security priorities and most pressing national tasks.

The foreign policy and national security priorities of the CIS members differ. The division of the CIS members into two main groups is a primary cause of the weakness of the CIS. The first group consists of those countries whose principal foreign and military policy priority is the pursuit of integration with the Russian Federation, which

Nika Chitadze is an alumnus of the George C. Marshall European Center for Security Studies. 
is a primary actor in this regard. This group contains members of the collective security agreement, including Belarus, Kazakhstan, Armenia, Kyrgyzstan, Tajikistan, and the Russian Federation itself. Additionally, five members of this organization are also participants in the Customs Union.

The second bloc within the CIS consists of members of the so-called GUUAM group (Georgia, Ukraine, Uzbekistan, Azerbaijan, Moldova). Members of GUUAM have many common problems, especially in the field of maintaining territorial integrity and fighting against separatism. Separatism in Georgia (in the regions of Abkhazia and South Ossetia), Azerbaijan (in Nagorno-Karabakh), and Moldova (in Transdniestria) represents one of the main political problems facing the members of this group. Some problems with separatism exist also on the Crimean Peninsula, in Ukraine. Another priority for the GUUAM members is to strengthen cooperation with respect to the Euro-Asian transport corridor and the transportation of Caspian oil to the West.

According to some analysts, this loose coalition may be transformed into a militarypolitical body, when aggression against one member state of GUUAM will be considered as an attack on other member states. This step will reduce the external threat, and will also raise the interest of Western countries, especially members of NATO, in dealing with such an organization. For the next few years it will be impossible for members of GUUAM to become plenipotentiary members of NATO, but the territory of the GUUAM states may become a zone of NATO strategic interests as a buffer zone between NATO and the Russian-centered collective security system.

\section{Prospects for the Solution of the Security Problems in the CIS}

Recent positive developments in Europe give us reason to say that there exist opportunities to solve at least some of the security problems facing the CIS countries. First of all, the most important factor is the process of NATO expansion and its increasing role in the world.

After the accession of new members from the Baltic and the Black Sea region to NATO membership, the agenda for the future of NATO will include the development of close cooperation with the CIS states. First of all, it is necessary to mention a speech by the former Secretary-General of NATO in August 2002 in Glasgow, when he argued that, "new and energetic relations with the countries of the Caucasus and Central Asia would be one of the symbols of NATO in the twenty-first century." Of course, this does not mean that states of the Caucasus will become fully-fledged members of NATO any time soon. But consultations concerning the experience of NATO in the sphere of security sector reform (civil-military relations), transition of national armed forces to NATO standards, defense management, strengthening of democratic institutions, and other areas will have a positive impact on democratization in the CIS and will help to strengthen the national security and national independence of these states, as well as to reduce the level of external threat.

In this respect, the Partnership for Peace (PfP) program has played an especially positive role. From the political point of view, the most important fact has been the clause that NATO would organize consultations with the members of PfP in cases 
where a PfP state was under a direct threat to its territorial integrity and national independence. This article repeats Article IV of the Washington treaty concerning the consultations of NATO member states in cases of foreign threat. The difference is that a necessary condition for it is active involvement in the PfP.

Another important factor for the solution of the security problems in the CIS lies in the economic realm. Economic development of post-Soviet states may create the basis for fighting terrorism, illegal migration, unemployment, and ethnic separatism. Economic development can defeat separatism because the de facto authorities and populations in the separatist regions will likely be willing to become engaged in economic processes that are going on at the national level if they have economic interests at stake. One of the positive examples is Cyprus, where representatives of the Turkish part of this state are trying to develop close contacts with their colleagues in the Greek part of the island. This process is being led primarily by the pursuit of economic development of the Greek part of Cyprus, and the prospect of joining the EU.

The implementation of international economic projects may give added impetus to the resolution of security problems in the former Soviet Union. Such projects include the Euro-Asia Transport Corridor project and the idea of renewing the Great Silk Road. The genesis of the new Silk Road program was launched in Brussels in 1993, when the European Commission invited the ministers of trade and transport of three Caucasus and five Central Asian states. At the conference it was decided to set up the Eurasian Transport Corridor and initiate a special regional technical assistance program, known as the Transport Corridor Europe-Caucasus-Asia (TRACECA). In September 1998, an international conference entitled "Revival of the Historical Silk Road" was held. Representatives of thirty-two Eurasian states and thirteen international organizations attended. The parties signed an agreement about starting the construction of a communication and transport corridor across Eurasia. At this stage, the main coordinator of TRACECA is the TACIS program of the European Union.

Other international projects within Eurasian territory are the Caspian oil and gas projects. According to the expectations of many experts, over the next ten to fifteen years the world demand for oil will rise by two to three percent per year. The Caspian region, with its sizeable reserves (200 billion barrels) has become a focus of the strategic interests of many Eurasian countries, as well as the United States. Over the past several years the U.S. and other democratic and economically developed states have come to consider the prospects for extracting and exporting Caspian oil and natural gas as a very important political and economic factor. One of the main aims for Western states is to lessen their energy dependence (particularly for oil and gas) on the politically unstable Middle East, and to seek alternate sources. The Caspian oil projects in Azerbaijan involve, in addition to U.S. companies, thirteen companies from Eurasia (nine European and four Asian). As for Kazakhstan, here another key regional player is involved, i.e. China. The major players in the energy field here are the U.S., the Russian Federation, the EU member states, Turkey, Iran, China, and Japan.

Thus, the expansion of NATO to the east and the successful fulfillment of these economic projects will create a basis for strengthening the security and national inde- 
THE QUARTERLY JOURNAL

pendence of the CIS countries. These factors will also play a critical role in addressing the restoration of territorial integrity in several post-Soviet republics. 